\title{
TRANSLATION AND CROSS-CULTURAL ADAPTATION OF THE PHYSICAL ACTIVITY QUESTIONNAIRE FOR OLDER CHILDREN INTO A BRAZILIAN PORTUGUESE VERSION
}

original paper

() University School of Physical Education in Wroclaw

DOI: https://doi.org/10.5114/hm.2020.88151

\section{DANIEL DAS VIRGENS CHAGAS ${ }^{1}$, DENIZAR VIANNA ARAÚJO ${ }^{1}$, DIRCEU GAMA ${ }^{1}$,} LARYSSA MACEDO ${ }^{1}$, ANDREA CAMAZ DESLANDES ${ }^{2}$, LUIZ ALBERTO BATISTA ${ }^{1}$

${ }^{1}$ Rio de Janeiro State University, Rio de Janeiro, Brazil

${ }^{2}$ Federal University of Rio de Janeiro, Rio de Janeiro, Brazil

\begin{abstract}
Purpose. To be used across different cultures, a physical activity questionnaire must be translated and cross-culturally adapted into target languages with a structured method. To date, there is no evidence supporting the use of the Physical Activity Questionnaire for Children (PAQ-C) in Brazil. Therefore, the purposes of this study were to translate and crossculturally adapt PAQ-C into the Brazilian Portuguese language and to determine its measurement properties.

Methods. Overall, 82 participants were initially recruited and the final PAQ-C version was applied in 52 children (28 boys, 24 girls). The translation and cross-cultural adaptation process was performed, and the measurement properties of the Brazilian Portuguese version of PAQ-C were determined in order to assess the internal consistency (Cronbach's alpha), test-retest reliability (ICC, intra-class correlation coefficient) and the level of agreement between test-retest measurements (Bland-Altman method). Paired t-test was used to compare PAQ-C means (test-retest).

Results. The meaning of the items was considered easily understood by the children. Cronbach's alpha reached acceptable values, ranging from 0.85 (test) to 0.87 (retest). ICC equalled 0.90, indicating excellent test-retest reliability. Paired t-test showed no significant difference between means. Bland-Altman plot proved a good level of agreement between two measurements. Conclusions. The translation and cross-cultural adaptation process was successful in reaching semantic equivalence between the original PAQ-C and the Brazilian Portuguese version; the measurement properties of the new PAQ-C version achieved a good level. Therefore, this study provided evidence supporting PAQ-C use among Brazilian children.
\end{abstract}

Key words: children, physical activity, measurement, cross-cultural adaptation, translated questionnaires, PAQ-C

\section{Introduction}

Physical activity can be defined as any bodily movement produced by skeletal muscles that results in energy expenditure [1]. A minimum amount of physical activity is necessary for a healthy development of an organism [2]. Also, undertaking regular physical activity plays a considerable role in preventing a variety of diseases [3].

Health researchers are often interested in assessing the physical activity levels in different populations, since childhood until old age. Currently, a wide variety of tools are used to evaluate the levels of physi- cal activity. Despite advances in methods to objectively monitor physical activity, much of recently funded health and behaviour research examining physical activity as an exposure or outcome relies on self-report as the principal method of data collection [4]. Self-report questionnaires are advantageous because they are economical and practical, allowing the researcher to test large numbers of participants in a short space of time [5].

Self-report questionnaires are also widely applied in assessing the physical activity levels in children [6]. Because of the diversity in the available questionnaires, it is not easy to determine which instrument is most

Correspondence address: Daniel das Virgens Chagas, Universidade do Estado do Rio de Janeiro (UERJ),

Ginásio de Esportes, Laboratório de Biomecânica e Comportamento Motor, Rua São Francisco Xavier, 524,

CEP: 20550-900, Maracanã, Rio de Janeiro/RJ, Brazil, e-mail: chagas_daniel@yahoo.com.br

Received: April 4, 2019

Accepted for publication: July 9, 2019

Citation: Chagas D, Araújo DV, Gama D, Macedo L, Deslandes AC, Batista LA. Translation and cross-cultural adaptation of the physical activity questionnaire for older children into a Brazilian Portuguese version. Hum Mov. 2020;21(1):32-39; doi: https://doi.org/10.5114/hm.2020.88151. 
suitable for this population [7]. However, the use of these instruments can be problematic because of the difficulty that children have in correctly interpreting questions and accurately recalling activity [8]. Nevertheless, this itself would not be a barrier to their use among children since each method has its own limitations, even those which objectively monitor physical activity. What researchers who are interested in assessing the physical activity levels in this population need is a valid and reliable self-report questionnaire.

One potentially valuable [5, 9] and promising selfreport questionnaire [7] for assessing the physical activity levels in children is the Physical Activity Questionnaire for Older Children (PAQ-C). PAQ-C is a self-administered 7-day recall questionnaire intended to assess habitual moderate to vigorous physical activity in older children [10]. While its criterion validity cannot be addressed because of the lack of a gold standard for measuring physical activity levels [7], evidence supports PAQ-C content [11], construct, convergent [12,13] and divergent validity [12], as well as good reliability $[8,10,11,13-15]$.

PAQ-C was originally developed for assessing the physical activity levels of children whose native language is English. While there are nearly 25 million of children aged 8-14 years in Brazil, to date there is no evidence supporting PAQ-C use for Brazilian children, whose native language is Portuguese.

Before being applied in Brazilian children, PAQ-C must be translated and cross-culturally adapted into the Brazilian Portuguese language with a structured method. Further, the psychometric properties of the translated PAQ-C version must be determined, since the validity of physical activity self-report measures can be a problem when these are used with target populations that differ from that for which they were originally developed [16]. Therefore, the purposes of this study were to translate and cross-culturally adapt PAQ-C into the Brazilian Portuguese language and to determine its measurement properties.

\section{Material and methods}

A total of 82 children aged 11-14 years between the $7^{\text {th }}$ and $9^{\text {th }}$ grades were recruited from a school in the city of Rio de Janeiro. Among them, 30 subjects were selected to explore both the meaning of the items and responses (pre-final version of PAQ-C). The final version was applied in 52 children ( 28 boys, 24 girls; mean age: $13.6 \pm 0.8$ years). The inclusion criteria involved literate students aged 8-14 years without records of learning disorders.
PAQ-C is appropriate for elementary school-aged children, approximately 8-14 years old, who are currently in the school system and have recess as a regular part of their school week. The summary score from PAQ-C is the average of the sum of the 9 item questions, each scored on a 5-point scale. Question 1 has a list with 22 items; the children report their frequency (no $=1$ point; $1-2$ times $=2$ points; $3-4$ times $=3$ points; $5-6$ times $=4$ points; 7 times or more $=5$ points) in each of them in the previous week; question 1 score is the average across all its items. Further, in the first question, it is allowed to report physical activities practised by children in the previous week which are absent in the list. On the other hand, questions 2-9 are entirely closed: children just answer how much physical activity they did. Question 10 is interpretative, since it refers to anything that prevented the child from doing normal physical activities.

The translation and cross-cultural adaptation process followed the guidelines originally proposed by Guillemin et al. [17] and later revised by Beaton et al. [18]. First, the original version of PAQ-C was translated independently by two bilingual translators whose mother tongue is the target language into two Brazilian Portuguese versions (T1 and T2). The translators of T1 and T2 were, respectively, a physical educator with $\mathrm{PhD}$ in Health Sciences and a teacher of the English language not familiarized with technical terminology concerning physical activity and exercise. A synthesis of $\mathrm{T} 1$ and T2 produced one common translation (T-12) based on a consensus of the translators. Then, the T-12 version was independently back-translated into English by two persons, blinded to the original version, Portuguese speakers with English as their mother tongue. Thereafter, an expert committee composed of bilingual health professionals with $\mathrm{PhD}$ in Health Sciences, a methodologist, a language professional, and the translators reviewed all the translations and reached a consensus on discrepancies. On the basis of this consensus was produced a pre-final version of PAQ-C.

The pre-final PAQ-C version was applied to 30 children in order to explore both the meaning of the items and responses. Considering that most children were not familiarized with some sports activities included in question 1 , it was decided to exclude these original items aiming to avoid a floor effect in the PAQ-C scores. With this preliminary analysis, the final version of PAQ-C was produced in the Brazilian Portuguese language.

The final PAQ-C version in Brazilian Portuguese was applied in 52 children who did not participate in 
D. Chagas, D.V. Araújo, D. Gama, L. Macedo, A.C. Deslandes, L.A. Batista, PAQ-C for Brazilian children

the pre-final version testing. The children were encouraged to discuss their possible doubts with the administrator of the questionnaire, who remained with them during all the testing. The questionnaire was administered by the same physical educator twice (test-retest). The time interval between the test and retest was 1 day, which is considered adequate to assess the reliability coefficient of a 7-day recall instrument [7]. The measurement properties of PAQ-C in the Brazilian Portuguese version were based on these 52 participants' data. By the rule of thumb, a sample size of at least 50 subjects is considered as adequate to study the measurement properties of physical activity questionnaires [19].

Descriptive statistics was provided for all measures. Internal consistency was assessed by using the Cronbach's alpha. Test-retest reliability was determined by intra-class correlation coefficient (ICC). ICC estimates and their $95 \%$ confidence intervals were based on a mean measurement $(\mathrm{k}=9)$, absolute agreement, 2 -way mixed model. A value of 0.70 or higher was considered as acceptable for both reliability coefficients [20]. The paired $t$-test was applied to compare means of PAQ-C (test-retest). The Bland-Altman method [21] served to determine the limits of agreement between test-retest measures. Data analysis was executed with the Statistical Package for the Social Sciences software version 22.0 (IBM, USA).

\section{Ethical approval}

The research related to human use has complied with all the relevant national regulations and institutional policies, has followed the tenets of the Declaration of Helsinki, and has been approved by the Ethics Committee of Rio de Janeiro State University (07617018.4.0000.5259).

\section{Informed consent}

Informed consent has been obtained from all individuals included in this study.

\section{Results}

The $\mathrm{T} 1$ and $\mathrm{T} 2$ versions were very similar. There were no relevant differences between them. Therefore, the consensus regarding the synthesis of T1 and T2 (T-12) was reached without difficulty. Similarly, the two back-translated versions presented few discrepancies, namely: 'to find out' vs. 'to determine'; 'honestly and accurately' vs. 'honestly and truly'; 'spare time' vs. 'leisure time;' 'mark only one option' vs. 'choose one option only'; 'following statements' vs. 'following options'. All these terms were considered as semanti- cally equivalent by the expert committee. Consequently, the second consensus, which led to obtaining the prefinal version, was also reached without difficulty.

Overall, both the meaning of the items and responses of the pre-final version were considered easy to understand by the children. However, most children were not familiarized with the following sports activities included in question 1: rowing, street hockey, floor hockey, cross-country skiing, ice hockey. In addition, they reported no practice with American football, baseball, or ice skating. In total, therefore, 8 of the 22 items of question 1 were not familiar to the children. Thus, question 1 of the Brazilian Portuguese version was composed of 14 items. The descriptive statistics of PAQ-C is provided in Table 1.

Table 1. Mean (standard deviation) values for 9 questions of PAQ-C and its summary score in test and retest

\begin{tabular}{lcc} 
& \multicolumn{3}{c}{$(n=52)$} \\
\cline { 2 - 3 } & PAQ-C test & PAQ-C retest \\
\hline Question 1 & $1.7(0.5)$ & $1.7(0.5)$ \\
Question 2 & $3.8(1.3)$ & $3.7(1.2)$ \\
Question 3 & $2.7(1.5)$ & $2.6(1.5)$ \\
Question 4 & $1.8(1.2)$ & $1.8(1.2)$ \\
Question 5 & $3.2(1.3)$ & $3.1(1.2)$ \\
Question 6 & $2.5(1.3)$ & $2.6(1.3)$ \\
Question 7 & $3.1(1.4)$ & $3.0(1.4)$ \\
Question 8 & $2.2(1.4)$ & $2.1(1.3)$ \\
Question 9 & $2.9(1.1)$ & $2.8(1.0)$ \\
Summary score* & $2.7(0.8)$ & $2.6(0.8)$ \\
\hline
\end{tabular}

PAQ-C - Physical Activity Questionnaire for Older Children * Summary score is the average of the sum of the 9 item questions of PAQ-C.

The internal consistency coefficients reached acceptable values (i.e. $\geq 0.70)$ and ICC $(2, \mathrm{k})$ indicated an excellent test-retest reliability [22] (Table 2). Moreover, the paired $t$-test showed no significant difference between means of PAQ-C $(p=0.062)$.

Table 2. Measurement properties of the Brazilian Portuguese version of PAQ-C: values of internal consistency (Cronbach's alpha), test-retest reliability (ICC), and mean difference ( \pm standard deviation) between test-retest measures (Bland-Altman)

\begin{tabular}{lc}
\cline { 2 - 2 } & Test-retest \\
\hline Cronbach's alpha & $0.85-0.87$ \\
ICC $(2, \mathrm{k})$ & 0.90 \\
Bland-Altman & $0.0567( \pm 0.2148)$ \\
\hline
\end{tabular}

PAQ-C - Physical Activity Questionnaire for Older Children, ICC - intra-class correlation coefficient 
The small differences across measurements (testretest) showed in the Bland-Altman plot indicated a good agreement between two measurements (Figure 1). Furthermore, the mean of test-retest scores explained only $0.1 \%$ of variance in differences between measurements $\left(\mathrm{R}^{2}=0.001, \mathrm{~F}=0.052, p=0.821\right)$. Therefore, there was no proportional bias between values acquired in test-retest measurements.

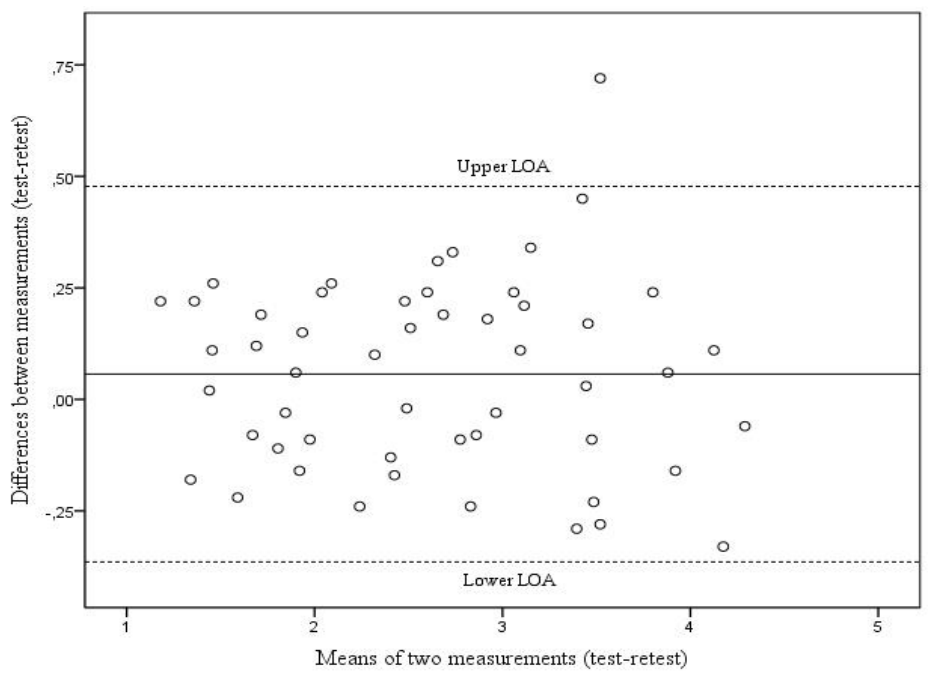

LOA - limit of agreement

Figure 1. Bland-Altman plot: difference against average of test and retest measurements (central line), with 95\% of LOAs (dotted lines). Lower LOA $=-0.3642$, upper

$$
\mathrm{LOA}=0.4776
$$

\section{Discussion}

The study aimed to translate and cross-culturally adapt PAQ-C into the Brazilian Portuguese language and to determine its measurement properties. Our findings suggested a good internal consistency of the Brazilian Portuguese version. Also, there was a good level of agreement between two measurements and excellent test-retest reliability. Therefore, the new PAQ-C version constructed in this study proved to be appropriate for use among Brazilian children.

Linguistic translation is necessary when adapting a measure for application in cross-cultural research [16]. Thus, the first step in the adaptation of PAQ-C into the Brazilian Portuguese language was the translation. There were no relevant differences between versions across the translation processes. Also, consensuses among the expert committee were reached without difficulty. These results can be explained by the fact that PAQ-C was originally developed to be applied in children population, with its language easy to understand. Also, there are no idiomatic expressions in the original version of $\mathrm{PAQ}-\mathrm{C}$, making the process to obtain the semantic equivalence between the original and target versions relatively smooth.

A key aspect in a self-report questionnaire refers to its whole understanding by the target community [23]. In fact, if a questionnaire is not easily understood by the respondents, its use must be avoided in this population. In this study, both the meaning of the items and responses of the Brazilian Portuguese version were considered easily understood by the children. These results suggest that the literacy level of the participants matched the literacy and cognitive demands of the Brazilian Portuguese version of PAQ-C.

Besides the translation process, the study aimed to cross-culturally adapt PAQ-C into the Brazilian Portuguese language. The term 'cross-cultural adaptation' is used to encompass a process that looks at both language and cultural adaptation issues in the process of preparing a questionnaire for use in a setting different from that for which it was originally developed [18]. Understanding the target community and its culture is critical for reducing biases and increasing the likelihood of accurate measurement [16]. Thus, if a questionnaire is to be applied across cultures, it should be not only translated well linguistically, but also adapted culturally [17, 18]. In fact, previous studies using questionnaires across cultures have modified them from the original version [24, 25]. Based on this premise, some original items of question 1 of PAQ-C were withdrawn from the Brazilian Portuguese version. While rowing, street hockey, floor hockey, crosscountry skiing, ice hockey, football (American), baseball, and ice skating can be well practised in the United States, these sports activities are not widespread among Brazilian children. In fact, this empirical assumption was corroborated in the pre-final PAQ-C version, when the questionnaire was preliminarily applied to a sample of children. Therefore, some original items were excluded from the final version, which aimed to avoid a floor effect in the PAQ-C scores.

On the other hand, there are other well-known physical activities performed by Brazilian children that are not included in question 1 in the original version of PAQ-C, such as futsal and other popular plays with a ball. However, the absence of these items seems not to be a bias for PAQ-C scores because children can include non-mentioned activities in question 1. Indeed, the assessed measurement properties of the translation and cross-cultural adaptation of PAQ-C corroborated this assertion.

Before use, every physical activity questionnaire should be evaluated for its psychometric properties 
D. Chagas, D.V. Araújo, D. Gama, L. Macedo, A.C. Deslandes, L.A. Batista, PAQ-C for Brazilian children

[23]. Thus, the measurement properties of the translation and cross-cultural adaptation of PAQ-C into the Brazilian Portuguese language were determined in this study. The level of agreement between two measurements, internal consistency, and test-retest reliability coefficients reached good levels. Also, there were no significant differences between means of PAQ-C scores (test-retest). Altogether, these findings provide evidence supporting PAQ-C use for Brazilian children.

This was the first study to translate and cross-culturally adapt PAQ-C into the Brazilian Portuguese language that followed systematic procedures such as those proposed by Guillemin et al. [17] and Beaton et al. [18]. Also, the study was pioneer to determine the measurement properties of the Brazilian Portuguese PAQ-C version. As practical application, the Brazilian Portuguese version of PAQ-C can be useful for researchers, physical educators, paediatricians and other health professionals interested in assessing the levels of physical activity among Brazilian children. Finally, the new version constructed in this study can have a widespread utility, since there are nearly 25 million of children aged 8-14 years in Brazil.

\section{Conclusions}

The translation and cross-cultural adaptation process was successful in reaching the semantic equivalence between the original PAQ-C and the Brazilian Portuguese version. Also, the measurement properties of the new PAQ-C version achieved a good level. Therefore, this study provided evidence supporting PAQ-C use among Brazilian children.

\section{Acknowledgements}

The authors would like to thank Ms. Rejane Miranda for her technical support.

\section{Disclosure statement}

No author has any financial interest or received any financial benefit from this research.

\section{Conflict of interest}

The authors state no conflict of interest.

\section{References}

1. Carpensen CJ, Powell KE, Christenson GM. Physical activity, exercise, and physical fitness: definitions and distinctions for health-related research. Public Health Rep. 1985;100(2):126-131.

2. Junger J, Kačúr P, Tlučáková L, Čech P, Bebčáková V. Physical activity of female students in secondary schools in the context of physical activity recommendations fulfilment. Hum Mov. 2017;18(3):67-73; doi: 10.1515/ humo-2017-0025.

3. Bergier J, Niźnikowska E, Bergier B, Acs P, Salonna F, Junger J. Differences in physical activity, nutritional behaviours, and body silhouette concern among boys and girls from selected European countries. Hum Mov. 2017;18(1):19-28; doi: 10.1515/humo-2017-0009.

4. Bowles HR. Measurement of activity and sedentary behaviors: closing the gaps in self-report methods. J Phys Act Health. 2012;9(Suppl. 1):S1-S4; doi: 10.1123/jpah. 9.s1.s1.

5. Thomas EL, Upton D. Psychometric properties of the physical activity questionnaire for older children (PAQ-C) in the UK. Psychol Sport Exerc. 2014;15(3):280-287; doi: 10.1016/j.psychsport.2014.02.002.

6. Loprinzi PD, Cardinal BJ. Measuring children's physical activity and sedentary behaviors. J Exerc Sci Fit. 2011; 9(1):15-23; doi: 10.1016/S1728-869X(11)60002-6.

7. Chinapaw MJ, Mokkink LB, van Poppel MN, van Mechelen W, Terwee CB. Physical activity questionnaires for youth: a systematic review of measurement properties. Sports Med. 2010;40(7):539-563; doi: 10.2165/ 11530770-000000000-00000.

8. Janz KF, Lutuchy EM, Wenthe P, Levy SM. Measuring activity in children and adolescents using self-report: PAQ-C and PAQ-A. Med Sci Sports Exerc. 2008;40(4): 762-772; doi: 10.1249/MSS.0b013e3181620ed1.

9. Biddle SJH, Gorely T, Pearson N, Bull FC. An assessment of self-reported physical activity instruments in young people for population surveillance: project ALPHA. Int J Behav Nutr Phys Act. 2011;8:1; doi: 10.1186/14795868-8-1.

10. Kowalski KC, Crocker PRE, Donen RM. The Physical Activity Questionnaire for Older Children (PAQ-C) and Adolescents (PAQ-A) manual. Saskatoon: University of Saskatchewan; 2004.

11. Crocker PR, Bailey DA, Faulkner RA, Kowalski KC, McGrath R. Measuring general levels of physical activity: preliminary evidence for the Physical Activity Questionnaire for Older Children. Med Sci Sports Exerc. 1997; 29(10):1344-1349; doi: 10.1097/00005768-19971000000011.

12. Bervoets L, Van Noten C, Van Roosbroeck S, Hansen D, Van Hoorenbeeck K, Verheyen E, et al. Reliability and validity of the Dutch Physical Activity Questionnaires for Children (PAQ-C) and Adolescents (PAQ-A). Arch Public Health. 2014;72:47; doi: 10.1186/2049-325872-47.

13. Kowalski KC, Crocker PRE, Faulkner RA. Validation of the Physical Activity Questionnaire for Older Children. Pediatr Exerc Sci. 1997;9(2):174-186; doi: 10.1123/ pes.9.2.174.

14. Wang JJ, Baranowski T, Lau WP, Chen TA, Pitkethly AJ. Validation of the Physical Activity Questionnaire for Older Children (PAQ-C) among Chinese children. Biomed Environ Sci. 2016;29(3):177-186; doi: 10.3967/ bes2016.022. 
15. Herazo-Beltrán AY, Domínguez-Anaya R. The reliability of a questionnaire regarding Colombian children's physical activity [in Spanish]. Rev Salud Publica. 2012;14(5):802-809.

16. Arredondo EM, Mendelson T, Holub C, Espinoza N, Marshall S. Cultural adaptation of physical activity selfreport instruments. J Phys Act Health. 2012;9(Suppl. 1):S37-S43; doi: 10.1123/jpah.9.s1.s37.

17. Guillemin F, Bombardier C, Beaton D. Cross-cultural adaptation of health-related quality of life measures: literature review and proposed guidelines. J Clin Epidemiol. 1993;46(12):1417-1432; doi: 10.1016/08954356(93)90142-N.

18. Beaton DE, Bombardier C, Guillemin F, Ferraz MB. Guidelines for the process of cross-cultural adaptation of self-report measures. Spine. 2000;25(24):3186-3191; doi: 10.1097/00007632-200012150-00014.

19. Terwee CB, Mokkink LB, Poppel MN, Chinapaw MJ, van Mechelen W, de Vet HC. Qualitative attributes and measurement properties of physical activity questionnaires: a checklist. Sports Med. 2010;40(7):525-537; doi: 10.2165/11531370-000000000-00000.

20. Terwee CB, Bot SD, de Boer MR, van der Windt DA, Knol DL, Dekker J, et al. Quality criteria were proposed for measurement properties of health status questionnaire. J Clin Epidemiol. 2007;60(1):34-42; doi: 10.1016/ j.jclinepi.2006.03.012.

21. Bland JM, Altman DG. Statistical methods for assessing agreement between two methods of clinical measurement. Lancet. 1986;327(8476):307-310; doi: 10.1016/ S0140-6736(86)90837-8.

22. Koo TK, Li MY. A guideline of selecting and reporting intraclass correlation coefficients for reliability research. J Chiropr Med. 2016;15(2):155-163; doi: 10.1016/j. jcm.2016.02.012.

23. Ainsworth BE, Caspersen CJ, Matthews CE, Mâsse LC, Baranowski T, Zhu W. Recommendations to improve the accuracy of estimates of physical activity derived from self-report. J Phys Act Health. 2012;9(Suppl. 1): S76-S84; doi: 10.1123/jpah.9.s1.s76.

24. Metsavaht L, Leporace G, Riberto M, Sposito MM, Del Castillo LN, Oliveira LP, et al. Translation and crosscultural adaptation of the lower extremity functional scale into a Brazilian Portuguese version and validation on patients with knee injuries. J Orthop Sports Phys Ther. 2012;42(11):932-939; doi: 10.2519/jospt.2012.4101.

25. Lima RF, Clemente FM, Vale RF. Attitudes toward physical education in Portuguese schools: middle and high school students. Hum Mov. 2018;19(4):64-70; doi: 10.5114/hm.2018.77327.
Physical Activity Questionnaire

(Elementary School)

Name: ...................... Age:

Sex: .............. M .............. F .............. Grade

Teacher:

We are trying to find out about your level of physical activity from the last 7 days (in the last week). This includes sports or dance that make you sweat or make your legs feel tired, or games that make you breathe hard, like tag, skipping, running, climbing, and others.

Remember:

1. There are no right and wrong answers - this is not a test.

2. Please answer all the questions as honestly and accurately as you can - this is very important.

Physical activity in your spare time: Have you done any of the following activities in the past 7 days (last week)? If yes, how many times? (Mark only one circle per row.)

Skipping

Rowing/canoeing

In-line skating

Tag

Walking for exercise

Bicycling

Jogging or running

Aerobics

Swimming

Baseball, softball

Dance

Football

Badminton

Skateboarding

Soccer

Street hockey

Volleyball

Floor hockey

Basketball

Ice skating

Cross-country skiing

Ice hockey/ringette

Other:

No $\quad 1-2 \quad 3-4 \quad 5-6 \quad \begin{aligned} & 7 \text { times } \\ & \text { or more }\end{aligned}$

$\begin{array}{lllll}\square & \square & \square & \square & \square \\ \square & \square & \square & \square & \square \\ \square & \square & \square & \square & \square \\ \square & \square & \square & \square & \square \\ \square & \square & \square & \square & \square \\ \square & \square & \square & \square & \square \\ \square & \square & \square & \square & \square \\ \square & \square & \square & \square & \square \\ \square & \square & \square & \square & \square \\ \square & \square & \square & \square & \square \\ \square & \square & \square & \square & \square \\ \square & \square & \square & \square & \square \\ \square & \square & \square & \square & \square \\ \square & \square & \square & \square & \square \\ \square & \square & \square & \square & \square \\ \square & \square & \square & \square & \square \\ \square & \square & \square & \square & \square \\ \square & \square & \square & \square & \square \\ \square & \square & \square & \square & \square \\ \square & \square & \square & \square & \square \\ \square & \square & \square & \square & \square \\ \square & \square & \square & \square & \square \\ \square & \square & \square & \square & \square \\ \square & \square & \square & \square & \square\end{array}$

1. In the last 7 days, during your physical education (PE) classes, how often were you very active (playing hard, running, jumping, throwing)? (Check one only.)

I don't do PE

Hardly ever

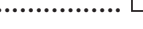

Quite often

Always

2. In the last 7 days, what did you do most of the time at recess? (Check one only.)

Sat down (talking, reading, doing schoolwork)

Stood around or walked around

Ran or played a little bit

Ran around and played quite a bit

Ran and played hard most of the time 


\section{HUMAN MOVEMENT}

D. Chagas, D.V. Araújo, D. Gama, L. Macedo, A.C. Deslandes, L.A. Batista, PAQ-C for Brazilian children

3. In the last 7 days, what did you normally do at lunch (besides eating lunch)? (Check one only.)

Sat down (talking, reading, doing schoolwork)

Stood around or walked around

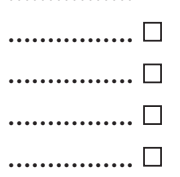

Ran or played a little bit

Ran around and played quite a bit

Ran and played hard most of the time

4. In the last 7 days, on how many days right after school, did you do sports, dance, or play games in which you were very active? (Check one only.)

None

time last week $\quad$................. $\square$

or 3 times last week ................. $\square$

times last week $\quad$.................. $\square$

times last week

5. In the last 7 days, on how many evenings did you do sports, dance, or play games in which you were very active? (Check one only.)

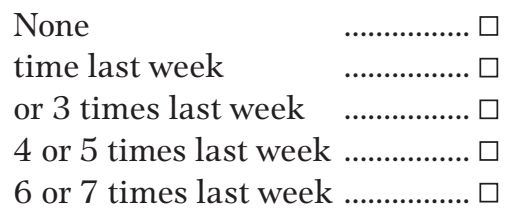

6. On the last weekend, how many times did you do sports, dance, or play games in which you were very active? (Check one only.)

\begin{tabular}{|c|c|}
\hline None & ………….... $\square$ \\
\hline time & \\
\hline or 3 times & ….............. \\
\hline 4 or 5 times & …............ $\square$ \\
\hline
\end{tabular}

7. Which one of the following describes you best for the last 7 days? Read all five statements before deciding on the one answer that describes you.

A. All or most of my free time was spent doing things that involve little physical effort

B. I sometimes (1-2 times last week) did physical things in my free time (e.g. played sports, went running, swimming, bike riding, did aerobics)

C. I often (3-4 times last week) did physical things in my free time

D. I quite often (5-6 times last week) did physical things in my free time

E. I very often (7 or more times last week) did physical things in my free time

8. Mark how often you did physical activity

(like playing sports, games, doing dance,

or any other physical activity) for each day last week.

\begin{tabular}{lccccc} 
& \multicolumn{3}{c}{ Little } & Very \\
Monday & None & bit & Medium & Often & often \\
Tuesday & $\square$ & $\square$ & $\square$ & $\square$ & $\square$ \\
Wednesday & $\square$ & $\square$ & $\square$ & $\square$ & $\square$ \\
Thursday & $\square$ & $\square$ & $\square$ & $\square$ & $\square$ \\
& $\square$ & $\square$ & $\square$ & $\square$ & $\square$
\end{tabular}

Friday

Saturday

Sunday

$\square$
$\square$
$\square$

$\begin{array}{lll}\square & \square & \square \\ \square & \square & \square \\ \square & \square & \square\end{array}$

9. Were you sick last week, or did anything prevent you from doing your normal physical activities? (Check one.)

Yes

No

If Yes, what prevented you?

Questionário de Atividade Física

(Ensino Fundamental)

Nome:

Idade:

Sexo:

... $\mathrm{F}$

Ano (série):

Professor:

Nós estamos tentando descobrir o seu nível de atividade física nos últimos sete dias (na última semana). Isso inclui esportes e danças que fazem você suar ou sentir as pernas cansadas, ou jogos que fazem você respirar com dificuldade, como brincar de pega-pega, pular corda, correr, escalar e outros.

Lembre-se:

1. Não existem respostas certas ou erradas - isso não é um teste.

2. Por favor, responda todas as questões da forma mais honesta e precisa - isso é muito importante.

Atividade física no tempo livre: Nos últimos 7 dias (última semana), você fez alguma das seguintes atividades? Se sim, quantas vezes? (Marque apenas um círculo por linha)

Pular corda

Patinação

Pega-pega

Caminhada

Andar de bicicleta

Corrida

Aeróbica

Dança

Natação

Badminton

Skate

Futebol

Voleibol

Basquetebol

Other:

$$
\text { Não } \quad 1-2 \quad 3-4 \quad 5-6 \text { ou mais }
$$

$\begin{array}{lllll}\square & \square & \square & \square & \square \\ \square & \square & \square & \square & \square \\ \square & \square & \square & \square & \square \\ \square & \square & \square & \square & \square \\ \square & \square & \square & \square & \square \\ \square & \square & \square & \square & \square \\ \square & \square & \square & \square & \square \\ \square & \square & \square & \square & \square \\ \square & \square & \square & \square & \square \\ \square & \square & \square & \square & \square \\ \square & \square & \square & \square & \square \\ \square & \square & \square & \square & \square \\ \square & \square & \square & \square & \square \\ \square & \square & \square & \square & \square \\ \square & \square & \square & \square & \square \\ \square & \square & \square & \square & \square\end{array}$

1. Nos últimos sete dias, durante sua aula de Educação Física (EF), com que frequência você ficou muito ativo (praticando muito, correndo, saltando, arremessando)? (Marque apenas uma opção)

Eu não faço EF

Quase nunca

Algumas vezes

Quase sempre

Sempre

$\square$
$\square$
$\square$
$\square$
$\square$
$\square$
$\square$
$\square$
$\square$
$\square$
$\square$
$\square$
$\square$
$\square$
$\square$
$\square$
$\square$


2. Nos últimos 7 dias, o que você fez na maior parte do seu tempo das horas vagas? (Marque apenas uma opção)

Fiquei sentado (conversando, lendo, fazendo trabalhos

da escola)

$\square$

Dei uma volta ou caminhada

Corri ou joguei um pouco

Corri e joguei bastante

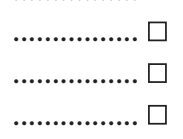

Corri e joguei a maior parte do tempo

3. Nos últimos sete dias, o que você normalmente fez no horário do almoço (além de almoçar)?

(Marque apenas uma opção)

Fiquei sentado (conversando, lendo, fazendo trabalhos da escola)

Dei uma volta ou caminhada

Corri ou joguei um pouco

Corri e joguei bastante

Corri e joguei a maior parte do tempo

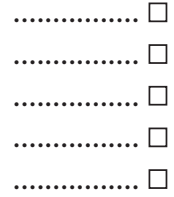

4. Nos últimos sete dias, quantos dias você fez esportes, dançou, ou praticou jogos que você fez muita atividade logo após a escola? (Marque apenas uma opção)

Nenhum

vez na semana passada

ou 3 vezes na semana passada ................. $\square$

vezes na semana passada $\quad$................. $\square$

vezes na semana passada

5. Nos últimos sete dias, em quantas noites você fez esportes, dançou, ou brincou com jogos nos quais você ficou muito ativo? (Marque apenas uma opção)

\section{Nenhuma}

vez na semana passada

ou 3 vezes na semana passada

4 ou 5 vezes na semana passada

6 ou 7 vezes na semana passada

6. No último fim de semana, quantas vezes você fez esportes, dançou, ou praticou jogos que você fez muita atividade? (Marque apenas um)

Nenhuma

1 vez

2-3 vezes

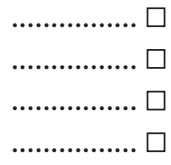

$4-5$ vezes

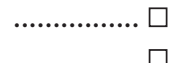

6 ou mais vezes

7. Qual opção a seguir descreve melhor você nos últimos 7 dias? Leia todas as cinco afirmações antes de decidir uma única resposta que descreve você.

A. Todo ou a maior parte do meu tempo livre foi gasto fazendo coisas que envolveram pouco esforço físico

B. Algumas vezes (1-2 vezes na última semana) fiz atividades físicas no meu tempo livre (por exemplo: fiz esportes, corri, nadei, pedalei, fiz aeróbica)

C. Eu frequentemente (3-4 vezes na última semana) fiz atividades físicas no meu tempo livre
D. Eu bem frequentemente (5-6 vezes na última semana) fiz atividades físicas no meu tempo livre

E. Eu muito frequentemente (7 ou mais vezes na última semana) fiz atividades físicas no meu tempo livre

8. Marque com que frequência você fez atividades físicas (como praticar esportes, jogar, dançar, ou alguma outra atividade física) para cada dia da semana passada.

$\begin{array}{lccccc} & \begin{array}{c}\text { Nen- } \\ \text { huma }\end{array} & \begin{array}{c}\text { Rara- } \\ \text { mente }\end{array} & \text { Média } & \begin{array}{c}\text { Frequente- } \\ \text { mente }\end{array} & \begin{array}{c}\text { Muito } \\ \text { frequente- } \\ \text { mente }\end{array} \\ \text { Segunda } & \square & \square & \square & \square & \square \\ \text { Terça } & \square & \square & \square & \square & \square \\ \text { Quarta } & \square & \square & \square & \square & \square \\ \text { Quinta } & \square & \square & \square & \square & \square \\ \text { Sexta } & \square & \square & \square & \square & \square \\ \text { Sábado } & \square & \square & \square & \square & \square \\ \text { Domingo } & \square & \square & \square & \square & \square\end{array}$

9. Você ficou doente na última semana, ou alguma coisa impediu você de fazer as atividades físicas normais? (Marque uma opção)

Sim

Não

Se sim, o que impediu você? 